\title{
䯣膜腫と周辺脳組織
}

\author{
中洲 敏·平野 朝雄·Josefina F. Llena · 志村 俊郎
}

\section{Meningioma and Underlying Brain}

\author{
Satoshi Nakasu, Asao Hirano, Josefina F. Llena and Toshiro Shimura \\ Division of Neuropathology, Department of Pathology, Montefiore Medical Center, New York, U.S.A.
}

\begin{abstract}
Twenty-eight non-operated supratentorial meningiomas were selected from the autopsy files of Montefiore Hospital to study the relationship between the brain and the tumor. Though meningiomas are usually well demarcated from the brain, their interface with the brain takes various forms, i.e., smooth type, lobular type, finger-like expansion type, and invasive type. The so-called "capsule" mainly consists of arachnoid membrane, arachnoid trabeculae, septae of the tumor and pial membrane. In several cases, there is no obvious connective tissue that can be called a "capsule" between the tumor and the brain. Vessels in the subarachnoid space are located between lobules of the tumor or surrounded by connective tissue. Sometimes, they are completely entrapped in the tumor. Loss of neurons, gliosis, cyst formation, edema and even calcification are seen in the underlying brain. The thickness of the underlying cortex does not always depend on the size of the tumor. Even small meningiomas, $2-3 \mathrm{~cm}$ in diameter, are sometimes associated with a thin cortex.
\end{abstract}

Key words: meningioma, capsule, brain, subarachnoid space, vessel

\section{I はじめに}

蹎膜腫は通常良性て脳上よく境界された腫瘍であり，䯣 膜腫自体の組織像や骨，硬膜上の関係については多くの報 告がなされている1,2,4,79,12,13!。しかし，髄膜腫の辺縁や脳 およびクモ膜下腔の組織との関倸については，系統だった 報告は少ない1,10,13!。我々は，Montefiore 病院に括ける剖 検例において，䯣膜腫と脳を含めた周辺組織しの関俰につ いて検討した。

\section{III対象および方法}

1948年より1982年までの35年間の頭部剖検例で，髄膜腫 症例のうち(1)非手術例，(2)大脳に接して発牛したもの，(3) 腫疸の辺縁部および直下の䒽組織がプレハララートとして保 存されているもの，の3 条件を渾た寸28例を選択し対象と した(Table 1)。こ扎らのら尚 symptomatic case は3 例で，
残りは incidental caseであった。また，11例は脳と腫瘍が 同一プレパラー上上にり，他は2つに分けて摽本作製が なされていた。

腫瘍の大きさは剖検記録より引用したが，記載のないも のはプレパラートより平均直佳を計算した。睡瘍の压迫に 上る大腷皮質の厚さは，もっと斗薄くなっている部分で判 定し，(H)：皮質が消失しているか紙状に薄くなっている もの，(十):皮質が明らかに薄くなっているが肉眼的に十 分認めらる厚さを保っているもの，(土）:脳は腫瘍により 陷没しているが皮質の厚さの变化はごく軽度のbの， (一) : 汪正常のbの，の4型に分けた。腫瘍が脳に向か ってとる辺縁の形態も4 型に分け, $\mathrm{S}$ 型(smooth type)： 肉眼的・顕微鏡的に汪ぼ平滑な辺縁をもつ女の，L型 (lobular type)：肉眼的に大きな凹凸を多つもの，F型 (finger-like expansion type)：顕微鏡的に小突起学脳に向名 って多数出しているが脳との境界は鮮明な子の，I 型( in-

\footnotetext{
モンテフィオーレ病院神経病理

Address reprint requests to: S. Nakasu, M.D., Department of Neurosurgery, Shiga University of Medical Science, Seta-tsukinowa-cho, Ohtsu 520-21.

受稿 1985年6月27日受理 1986年. 4 月3011
} 
Table 1 Autopsy cases of meningiomas

\begin{tabular}{|c|c|c|c|c|c|c|c|}
\hline $\begin{array}{l}\text { Case } \\
\text { No. }\end{array}$ & $\begin{array}{l}\text { Age, } \\
\text { Sex }\end{array}$ & $\begin{array}{l}\text { Symp- } \\
\text { toms }\end{array}$ & Location & $\begin{array}{l}\text { Size } \\
(\mathrm{cm})\end{array}$ & Histology & $\begin{array}{l}\text { Cortical } \\
\text { change }^{*}\end{array}$ & $\begin{array}{l}\text { Type of } \\
\text { tumor }\end{array}$ \\
\hline 1 & $64, F$ & - & $\begin{array}{l}\text { parietal } \\
\text { convexity }\end{array}$ & 6.3 & fibrous & H & $\mathbf{L}$ \\
\hline 2 & $68, F$ & + & $\begin{array}{l}\text { sphenoid } \\
\text { ridge }\end{array}$ & 5.5 & $\begin{array}{l}\text { meningo- } \\
\text { theliomatous }\end{array}$ & $H$ & $\mathrm{~F}$ \\
\hline 3 & $63, F$ & + & $\begin{array}{l}\text { frontal } \\
\text { convexity }\end{array}$ & 3.5 & $\begin{array}{l}\text { meningo- } \\
\text { theliomatous }\end{array}$ & H & I \\
\hline 4 & $61, \mathrm{~F}$ & - & $\begin{array}{l}\text { olfactory } \\
\text { groove }\end{array}$ & 2.7 & $\begin{array}{l}\text { meningo- } \\
\text { theliomatous }\end{array}$ & \# & $\mathrm{F}$ \\
\hline 5 & $89, \mathrm{M}$ & - & $\begin{array}{l}\text { frontal } \\
\quad \text { convexity }\end{array}$ & 2.0 & fibrous & H & $\mathbf{I}$ \\
\hline 6 & $94, \mathbf{M}$ & - & $\begin{array}{l}\text { frontal } \\
\quad \text { convexity }\end{array}$ & 8.7 & $\begin{array}{l}\text { meningo- } \\
\text { theliomatous }\end{array}$ & + & $\mathrm{L}$ \\
\hline 7 & $68, \mathrm{M}$ & + & $\begin{array}{l}\text { sphenoid } \\
\text { ridge }\end{array}$ & 4.7 & $\begin{array}{l}\text { meningo- } \\
\text { theliomatous }\end{array}$ & + & $\mathrm{L}$ \\
\hline 8 & $97, \mathrm{~F}$ & - & $\begin{array}{l}\text { olfactory } \\
\text { groove }\end{array}$ & 4.6 & fibrous & + & $\mathrm{L}$ \\
\hline 9 & $83, \mathrm{~F}$ & - & $\begin{array}{l}\text { parietal } \\
\text { convexity }\end{array}$ & 3.2 & fibrous & + & $\mathrm{S}$ \\
\hline 10 & $83, \mathrm{~F}$ & - & $\begin{array}{l}\text { frontal } \\
\quad \text { convexity }\end{array}$ & 3.0 & transitional & + & L \\
\hline 11 & $65, \mathrm{~F}$ & - & parasagittal & 2.7 & transitional & + & $\mathrm{S}$ \\
\hline 12 & $72, \mathbf{F}$ & - & falx & 2.0 & angiomatous & + & F-L \\
\hline 13 & $64, \mathrm{~F}$ & - & falx & 2.0 & $\begin{array}{l}\text { meningo- } \\
\text { theliomatous }\end{array}$ & + & $\mathrm{L}$ \\
\hline 14 & $67, \mathbf{F}$ & - & $\begin{array}{l}\text { parietal } \\
\text { convexity }\end{array}$ & 2.0 & transitional & + & $\mathrm{s}$ \\
\hline 15 & $68, \mathbf{F}$ & - & $\begin{array}{l}\text { frontal } \\
\quad \text { convexity }\end{array}$ & 2.0 & psammomatous & + & $\mathrm{F}$ \\
\hline 16 & $65, \mathbf{F}$ & - & $\begin{array}{c}\text { olfactory } \\
\text { groove }\end{array}$ & 1.4 & transitional & + & S \\
\hline 17 & $69, \mathbf{F}$ & - & falx & 1.0 & $\begin{array}{l}\text { meningo- } \\
\text { theliomatous }\end{array}$ & + & F-L \\
\hline 18 & $59, \mathbf{F}$ & - & $\begin{array}{l}\text { parietal } \\
\text { convexity }\end{array}$ & 2.8 & psammomatous & \pm & S \\
\hline 19 & $68, \mathbf{M}$ & - & $\begin{array}{l}\text { occipital } \\
\text { convexity }\end{array}$ & 2.3 & fibrous & \pm & $\mathrm{L}$ \\
\hline 20 & $79, \mathbf{F}$ & - & parasagittal & 2.0 & psammomatous & \pm & s \\
\hline 21 & $76, \mathrm{~F}$ & - & $\begin{array}{l}\text { frontal } \\
\text { convexity }\end{array}$ & 2.0 & psammomatous & \pm & S \\
\hline 22 & $70, \mathrm{M}$ & - & $\begin{array}{l}\text { sphenoid } \\
\text { ridge }\end{array}$ & 1.8 & $\begin{array}{l}\text { meningo- } \\
\text { theliomatous }\end{array}$ & \pm & $\mathrm{s}$ \\
\hline 23 & $86, F$ & - & $\begin{array}{l}\text { frontal } \\
\text { convexity }\end{array}$ & 1.5 & transitional & \pm & $\mathrm{S}$ \\
\hline 24 & $70, \mathrm{~F}$ & - & parasagittal & 1.5 & fibrous & \pm & S \\
\hline 25 & $89, F$ & - & $\begin{array}{l}\text { frontal } \\
\text { convexity }\end{array}$ & 1.5 & psammomatous & \pm & $\mathrm{S}$ \\
\hline 26 & $87, \mathrm{~F}$ & - & $\begin{array}{l}\text { frontal } \\
\text { convexity }\end{array}$ & 1.0 & fibrous & - & $\mathbf{L}$ \\
\hline 27 & $74, \mathrm{M}$ & - & $\begin{array}{l}\text { olfactory } \\
\text { groove }\end{array}$ & 0.7 & transitional & - & $\mathrm{S}$ \\
\hline 28 & $85, M$ & - & $\begin{array}{l}\text { frontal } \\
\text { convexity }\end{array}$ & 0.5 & $\begin{array}{l}\text { meningo- } \\
\text { theliomatous }\end{array}$ & - & $\mathrm{S}$ \\
\hline
\end{tabular}

${ }^{*}$ Cortical change $(\mathbb{H})$ : cortex is almost lost; $(+)$ : apparently thin; $( \pm)$ : equivocal; $(-)$ : normal. $\mathrm{S}$ indicates smooth type; L, lobular type; $\mathbf{F}$, finger-like expansion type; I, invasive type. 


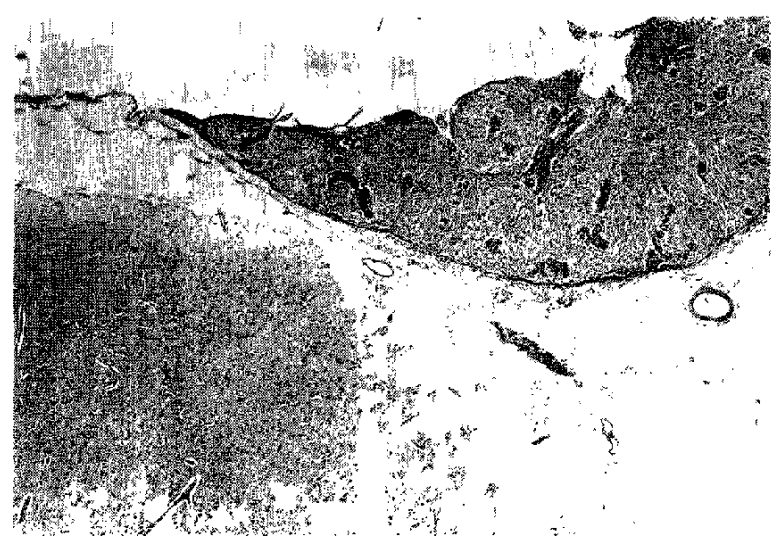

Fig. 1 Case 27. Small meningioma with visible subarachnoid space and intact cerebral cortex. Arachnoid membrane is directly in contact with the meningioma. HE stain, $\times 100$.

vasive type）：脳との境界が比較的不鮮明なもの，とした．

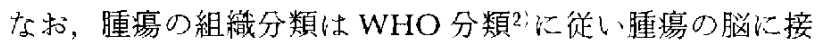
した部分で判定したが，hemangiopericytomaは除外した。

\section{III 結 果}

\section{1. クモ膜下腔}

ごく小さな髄膜腫では，大脸皮質と腫煌との間に十分な クモ膜下㴔が存在した（Fig． 1)，髄膜腫の下面や側面には 多数の arachnoid trabeculae が腫瘍表面に移行し，膜様の 構造を形成し睡瘍を覆っているように見觉た。腫陽が大き くなるに従い夕モ膜下腔は狭くなり，脳実質と接触し区还百 するよろになって(Fig. 2)，時に前述の腫瘍周囲の結合織

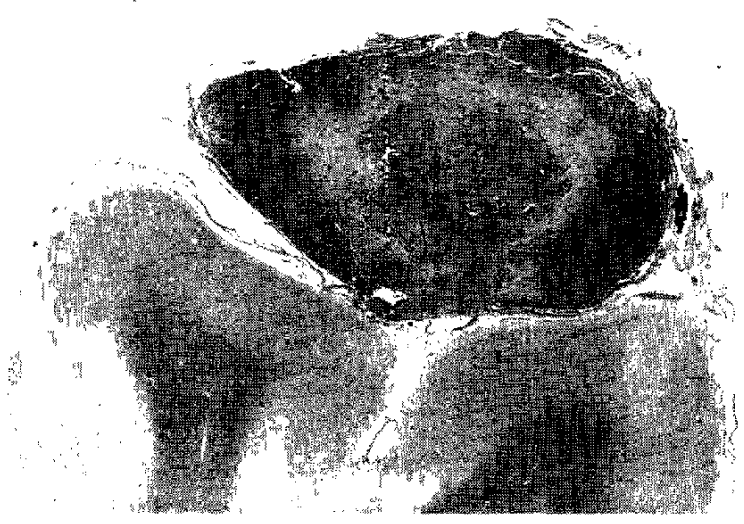

Fig. 2 Case 24. Small meningioma with compressed subarachnoid space and intact cerebral cortex. HE stain, $\times 4.8$.

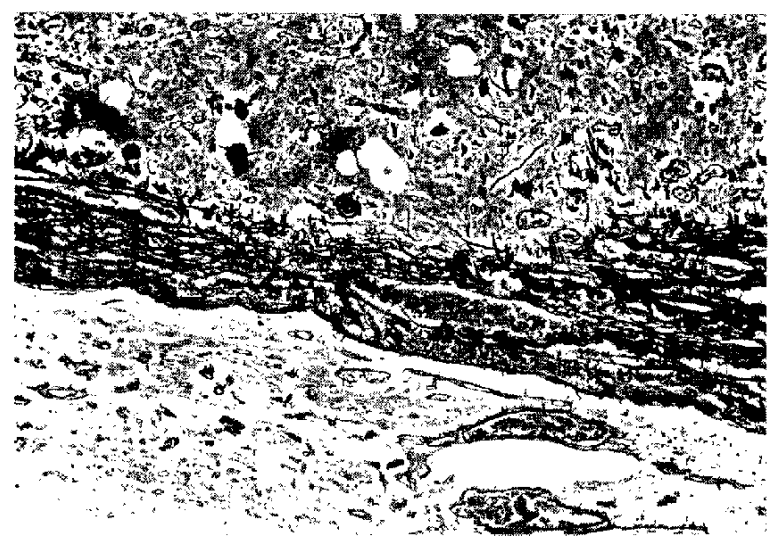

Fig. 3 Case 8. Abundant connective tissue fibers are seen between the meningioma and the damaged brain tissue. The thick connective tissue layer is generally refered to as the "capsule" of the meningioma. Reticulin stain, $\times 250$.

は脸軟膜々区別できなくなっていた(Fig. 3)。しかしここ のよらな腫瘍と脳との間に認机る結合織については, ごく少量のもの (Fig. 4B)から，有意な厚みをもつもの (Fig. 3)までさまざまであった。

クモ膜下腔への細胞浸潤は，ま玌にかなり著明なことも あるが通常蚛軽度で, lymphocyte, plasma cell, macrophage などが認められることがある、クモ膜下孟の血管は，腫瘍 の成长とともに腫瘍と脳の間に扷み込本れる訳であるが， 脳が强く生迫されている場合にも動静脈は内腔を保ってお り，腫瘍あるいは絬合織がそれる取り囲もよらな形をと。 ていることが多い(Fig. 5A)、極端な場合には血管が完全 に腫瘍の中に取り込まれ，そこから脳に向がて伸展した 分枝を出すような像を古していた(Fig. 5B)。このよらな 像は，腫瘍が $\mathrm{F}$ 型を示古場合によく認めら扎る所見であ z.

2. 脳

周辺脳と腫瀑は通常はっさり境界されて扰り，前述の上 らに腫瘍の辺絯形態から S 型(Fig. 1，2)，L型(Fig. 4)，F 型(Fig. 6)，I型（Fig.7）の4 型飞分计た。しかし，それぞ れの移行型の上らな皮のが存在しその区分は必ずしも明確 ではなく，特に F 型を示す場合，小腫瘍で L 型との移行 型をボす例が認められた（Fig. 5A). I 型に区分されたのは 2 例であるが，いずれも glioma などに認められるよらな 混在の形態でなく，大束かな境界が存在した，しかし，二 のような型をとる場合，脳と腫瘍の間を多数の小血管が交 通して和り(Fig. 7)，これは他のS 型・L型・F型ではみ られない所見であった。

脳自体の変化としては, 神経細胞の脱落, gliosis, 


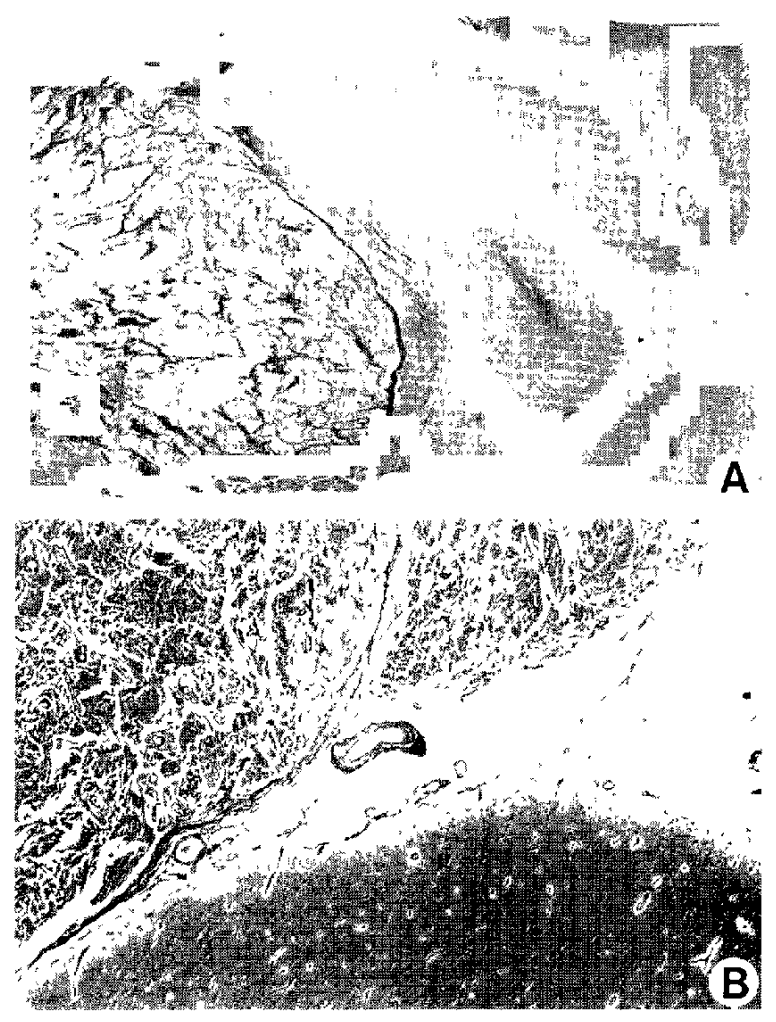

Fig. 4 Case 6 A Large lobulated meningioma compressing underlying cerebral cortex Arrow indicates a blood vessel in the almost totally obliterated subarachnord space. HE stan, $\times 8$ B. Large meningioma with poorly formed so-called "capsule", composed manly of the arachnoid membrane and its trabeculae. Reticulin stain, $\times 100$

edema, cystic change，小石灰沈着像 (F1g 8)などが办られ， これらがさまさまな程度に詔められた。脳皮質の厚さは， 腫場が比較的小さな場合には皮筫の厚さを伍とんと变える ことなく脳が陥没し，皮質の構築に乎大きな変化はない (Fig. 2)が，大きくなるにつ机て皮質が薄くなり，細胞自 体与扁平な形心変形し(Fig. 8)，つ小纱消失してしま 5，皮筫の薄さが(十) 群の症例では腫瘍の平均直佳は 4.0 $\mathrm{cm},(+)$ 群 $3.1 \mathrm{~cm},( \pm)$ 群 $1.9 \mathrm{~cm},(-)$ 群 $0.7 \mathrm{~cm}$ と汪汪大 きさに並行する傾向があったが，個々の腫瘍をみるとわす が $1 \mathrm{~cm}$ の腫瘍でも脳に強く食い込んでいたり，2〜3cm

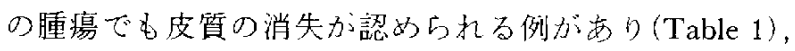
腫瘍の大きさ以外の要因も大きい上考充られた。

\section{$\mathbf{N}$ 考察}

通常, 髓膜腫は encapsulate された腫瘍といら表現が使 われるぶ，capsule 自体に棓项した報告は少なく5,13)，その
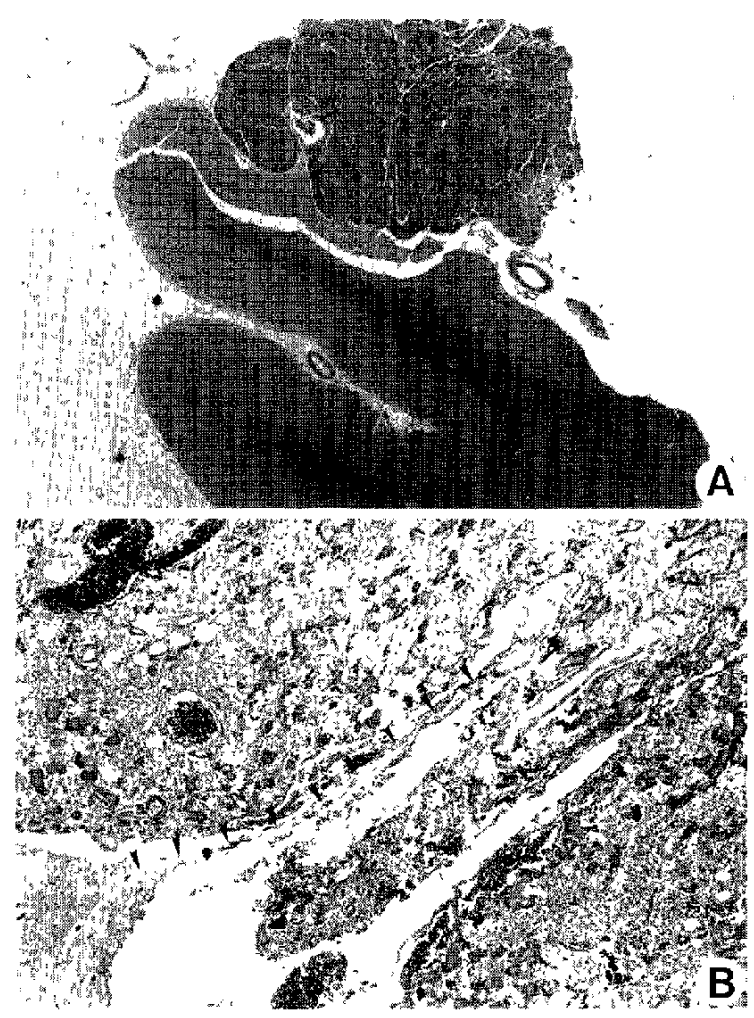

Fig. 5 A: Case 17 Menıngioma with small lobules abutting the cerebral cortex. Arrow indicates a cortical vein entrapped withın the tumor. HE stain, $\times 8$ B: Case 15 Higher magnification of a blood vessel entrapped by the tumor. Arrowheads indicate the stretched segment of the vessel as it goes into a Virchow-Robin space $\mathrm{HE}$ stain, $\times 100$

ため常に結合織の capsuleを被っているという印象を与え る傾向がある。しかし実際に慓本次見ると，結合織が非常 に少なく, capsuleといらようなはっきりした組織が認め

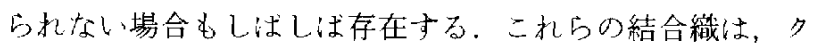
モ膜, arachnoid trabeculae 抒よび腫瘍の septae 上移行し でり，また腫場が大きくなると脳軟膜との区別もつきが たく, 腫瘍固有の capsule といらよりこれら周帇組織の集 合体で苏る上考兄ら机る。杰大，invasiveに発育寸る腫瘍 のみならす13!，通常の良性な腫瘍でも結合織をとんど伴 わないことがあるとには留意すべきてある。詣膜腫が静 脈洞を閉塞したり，めるいは脳底部の動脈を卷き込んだり することは知られている 具体的な報告はなされていない，我々の症例ではこれらの 小血管は能膜腫の宿没部にあることが多く，突出部にある 場合にも腫瘍あるいは結合織に囲交れたりして少なく上も 完全閉塞している像は認如られず, 静脈洞が剈道膜腫によっ 


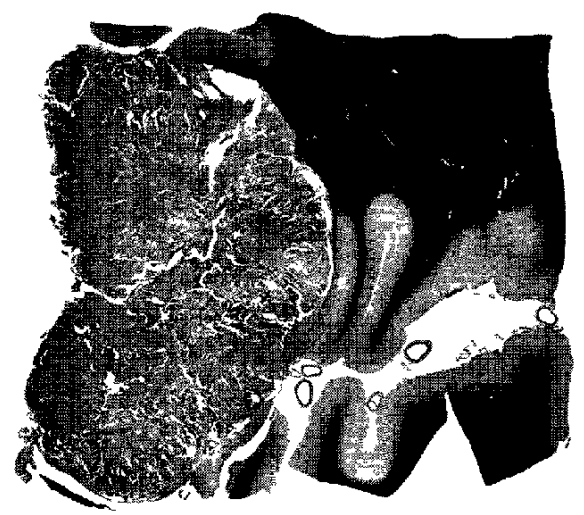

A

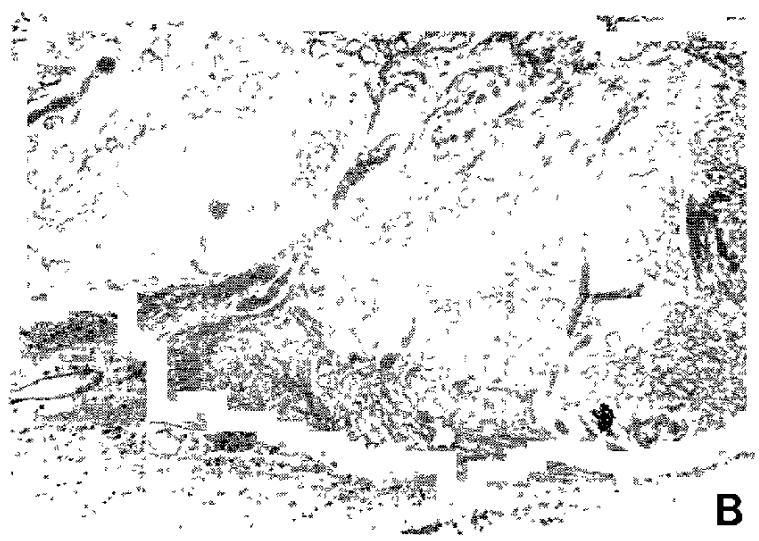

Fig 6 Case 4 A. Olfactory groove meningroma compressing the rectal gyrus In the arca where the cerebral cortex is lost, the white matter is in dircet contact with the tumor Myelin stain, $\times 3$ B Irregular protrusion of the meningioma into gliotic brain parenchyma HE stain, $\times 250$

てしはしは狭害あるい法閉塞されるのと対照的で茄った。 东た，時にりモ膜下腔の小血管か腫湯内に取り迟まれ，乙 こから伸展した分枝老脳に送っている像が認女口れ，手術 時に腫瘍の feeding arteryと見䛊らないよら怔意が必要て あるら。史たこれらの entrapされた血管から出る分枝

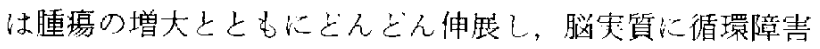
起こしたり，专扎には破綻し出血する可能性屯るる。

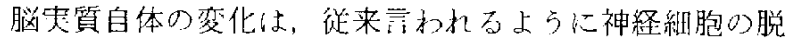
落, gliosis, edema, cyst formation tとて施 $\eta^{1,2,10,13}$ ，時に

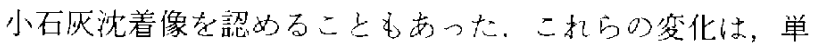
に腫痬の区迫たけてなく循環障害に起因するものも想起さ 狄ており13，我々の症例ても脳从血管が著明に搪張してい るものがあったここれらに上る脳皮質の变化は，腫瘍の大 きさによるだけではなく，扣そらく腫瘍の位䈯や脳の萎樎 の程度，男るいは腫陽の発育の速さなど関係してくるで あら5。また，皮質の消失の程度と腫陽が脳に的かってと
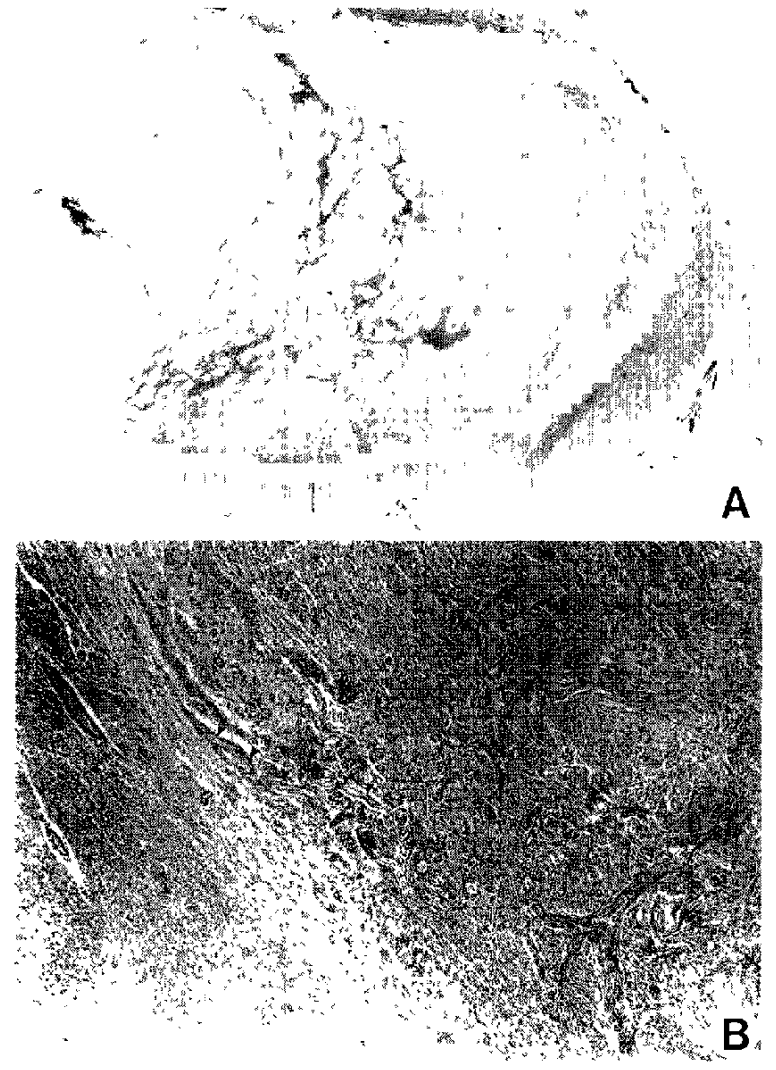

Fig 7 Case 5 A. Meningioma compressing the brain The cerebral cortex is lost and the tumor is adhcrent to the white matter Cross section of an artery is indicated by the arrow. HF stain, $\times 76$ B Interface between the meningioma and underlying white matter There is poor demarcation between the two, and a small vessel crosses the brain-tumor junction (arrowheads) HE stain, $\times 100$

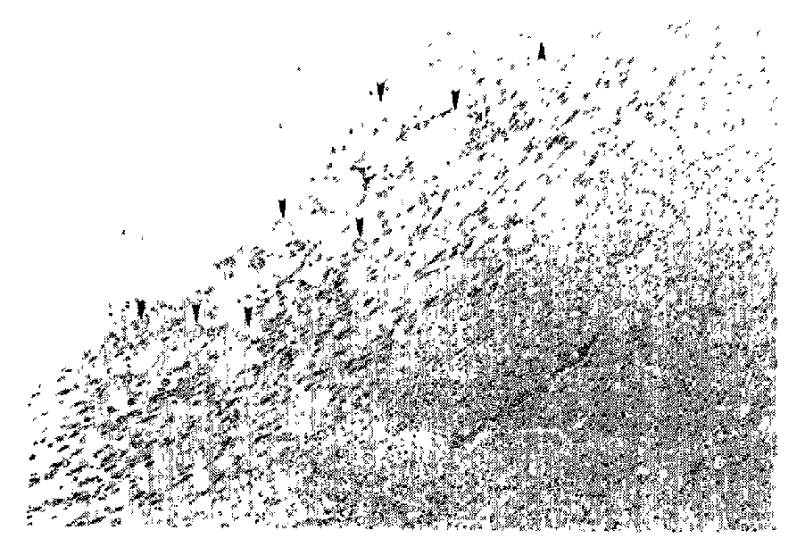

F 1 g 8 Case 13 Flattened and severely distorted cerebral cortex There are many small calcific globules (arrowhead) in the superficial portion of the cortex. Nissic stain, $\times 250$ 
る辺緣の形態との間にも，ある程度の関係があることにも 注日すべきである。腫痬に伴ら皮質の障害が強いものには， I 型やF 型を示すものが多かった(Table 1)，しかし，前 述のよらに F 型と L 型との間に移行型が存在し，特に小 腫痬の場合に F 型とL 型の中間の型をとって脳に强く食 い込んでいるものがあった。杰た，F型が再手術時に I 型 に变化した例も報告されて扣り2'，これらの腫瘍の辺縁は 成長過程で変化しうるものであり，腫瘍自体の性格だけで なく介在する脳軟膜や血管の barrier としての働きや，腫 瘍の成長に伴って起こる脳皮質の構造の変化などる関与し ている可能性が大きい.

個々の腫瘍讱縁の形態については，すでに報告がみられ る1-3,10,11,13が，その意味については不明なことが多く，他 になんら悪性所見のない腫瘍でも脳に浸潤している例も報 告されている ${ }^{11)}$ また，軟膜を越えて発育しているものは I 型として扱われていることも多い3,13)が，我々のF 型の 症例では脳との境界がはっきりしていることから独立した bのとして扱い，脳組織を腫瘍内に認めるなど境界が比較 的不鮮明なるのをI 型とした。しかしこの場合にも，一般 に䯣膜腫の細胞は互いに細胞閒の接着が密のため，脳軟膜 を越えて発育する場合もバラバラになって脳組織内に浸潤 することがなぐ，gliomaなどの浸潤形式とはまったく異 なっていた。このような各辺縁型の頻度については，我々 の症例は剖検例から選ばれた incidental case 索中心にした わのであるため明確にしえないが, Crompton ら゙の報告 では手術例121例中辺縁部が判断可能であった70例のうち， 17 例で脳への浸潤が認められたとしている。一五， Simpson ${ }^{11}$ は3.7\%で浸潤が認められたとして和り，報告者 によって多少違いがある。これらの違いは，手術例では時 によって辺縁部が十分に検索しえないことが原因と思われ る、このような個々の辺縁型のるつ意味を明らかにするた めには，剖検例のみならす臨床歴あるいはCT スキャンな どの放射線学的な検討を含めた総合的な判断が必要である 5.

\section{$\mathrm{V}$ ま と}

Montefiore 病院に扮活る剖検例より28例の非手術髄膜腫 症例を選択し，脳との関係につき検討を行った。

1. 䯣膜腫の capsule は, クモ膜, arachnoid trabeculae, 軟膜，腫痬の septaeなどより形成されていたが，汇とん ど capsule と呼べる汪どの結合織のないものもまれではな
かった。

2.クモ膜下の血管は腫場の陥没部に存在したり，時に 腫瘍内に取り这まれていることがあったが，腫瘍の王迫に より閉塞している像は明らかにできなかった。

3. 腫瘍による脳の变化は汪ぼ腫瘍の大ささに比例する 傾向があったが，小腫痬でも皮質の消失をきたすものがあ り，他の要因による影響我大きいと考えら扎た。

4. 腫堭の辺縁を smooth type, lobular type, finger-like expansion type, invasive typeに分けて症例を提示し，それ らの形態につき検討した。

\section{文献}

1) Boldrey E: The meningiomas, in Minckler $\mathrm{J}$ (ed) : Pathology of the Nervous System. New York, McGraw Hill, 1968, pp 2125-2144

2) Burger PC, Vogel FS: Surgical Pathology of the Nervous System, ed 2. New York, John Wiley \& Sons, 1982, pp 84-106

3) Crompton MR, Gautier-Smith PC: The prediction of recurrence in meningiomas. J Neurol Neurosurg Psychiat 33: 80-87, 1970

4) Cushing H, Eisenhardt L: Meningiomas. Their Classification, Regional Behavior, Life History and Surgical Results. Springfield, CC Thomas, 1938

5) Globus JH: The meningiomas. Res Publ Ass Res Nerv Ment Dis 16: 210-265, 1935

6) 平野朝雄, 松井孝嘉，岩田 誠：カラーフトラス神経病理. 東京, 医学書院, 1980, p 149

7) Kepes JJ: Meningiomas. Biology, Pathology and Differential Diagnosis. New York, Masson, 1982, pp 51-149

8) Lapsle J, Netsky MG, Zimmerman HM: The pathology of meningiomas. A study of 121 cases. Amer J Path 28: 757-791, 1952

9) Russell DS, Rubinstein LJ: Tumors of meningen and related tissue: Pathology of Tumors of the Nervous System. London, Edward Arnold, 1977, pp 65-100

10) Scherer HJ: Influence des tumeurs meningees sur le tissu cerebral. Rev Neurol (Paris) 66: 307-322, 1936

11) Simpson $D$ : The recurrence of intracranial meningiomas after surgical treatment. J Neurol Neurosurg Psychiat 20: 22-39, 1957

12) World Health Organization: Histological Typing of Tumor of the Central Nervous System. Geneva, WHO, 1979, p 21

13) Zülch $\mathrm{KJ}$ : Meningioma, in Olivecrona $\mathrm{H}$, Tonnis $\mathrm{W}$ (eds): Handbuch der Neurochirurgie, vol 3. Berlin, Springer, 1956, pp 399455

[別刷請求先：甬520-21 大津市瀨田月輪町, 滋賀医科大学脳神 経外科, 中洲 敏] 